\title{
Implementation of a penicillin allergy skin test
}

\author{
Aparecida Tiemi Nagao-Dias*1, Ana Carla Pereira ${ }^{1}$, Michelly Freitas e Silva ${ }^{1}$, \\ Eugenie Desiree Rabelo Néri², José Wilson Accioly ${ }^{3}$, Janete Elisa Soares Lima ${ }^{4}$
}

\author{
${ }^{1}$ Department Clinical Analysis and Toxicology, Faculty of Pharmacy, Federal University of Ceará, \\ ${ }^{2}$ Pharmacy sector, Walter Cantídio University Hospital; ${ }^{3}$ Department. of Dermatology, Walter Cantídio University Hospital, \\ ${ }^{4}$ Department Pharmacy, Faculty of Pharmacy, Federal University of Ceará
}

\begin{abstract}
The penicillin allergy skin testing is the only accurate and reliable test for penicillin hypersensitivity mediated by IgE. It is useful for identifying patients with doubtful history of allergy. Positive test for major and minor determinants presents a positive predictive value of $50 \%$ and negative predictive value of $99 \%$. In Brazil, the Ministry of Health suggests a protocol for in house made reagents, since they are not commercially available. As the referred protocol does not mention some important details about the test procedures, we propose in the present work to implement them, critically evaluating each step in order to allow the protocol establishment at any health service, with quality and safety.
\end{abstract}

Uniterms: Penicilin/allergy. Penicilin/cutaneous test. Skin test/penicilin allergy. Betalactamic/ hipersensitivity

\begin{abstract}
O teste cutâneo para alergia imediata a penicilina é o único teste validado internacionalmente, sendo que sua grande utilidade reside na avaliação de pacientes com história positiva de alergia a penicilina. O teste positivo para determinantes principais e secundários da penicilina apresenta um valor preditivo positivo de $50 \%$ e valor preditivo negativo de 99\%. Em nosso meio, o Ministério de Saúde disponibiliza um protocolo para o preparo dos reagentes, uma vez que os mesmos não estão disponíveis comercialmente. Como o referido protocolo não apresenta maiores detalhes sobre o cuidado relativo às etapas de preparo das soluções, bem como faltam algumas considerações no que tange a realização do teste, propusemonos no presente trabalho operacionalizar o teste, avaliando de forma crítica e minuciosa cada etapa, de forma que outros profissionais possam reproduzi-lo de maneira mais segura e eficaz.
\end{abstract}

Unitermos: Penicilina/alergia. Penicilina/teste cutâneo. Teste cutâneo/alergia penicilina. Betalactâmico/ hipersensibilidade.

\section{INTRODUCTION}

The beta-lactamic drugs, among them the penicillins, are considered to be the first choice in a variety of pathologies, such as pneumococcal pneumonia, cerebral abscess, bacterial meningitis, syphilis, rheumatic fever, and post streptococcal glomerulonephritis (São Paulo, 2003). However, the fear of a possible previous history of drug allergy commonly leads to the use of alternative antibiotics (Forrest, 2001).

Although the percentage of patients with a suggestive history of penicillin allergy is about 0.7 to $10 \%$, only 10

\footnotetext{
*Correspondence: A. T. Nagao-Dias. Departamento de Análises Clínicas e Toxicologicas, Rua Capitão Francisco Pedro, 1210, 60430-370 - Fortaleza - CE, Brazil. E-mail: tiemindi@yahoo.com.br
}

to $30 \%$ of them present positive cutaneous test (Forrest, 2001). Many suggestive cases of drug allergy are, in fact, neurovegetative disturbances or vasovagal reactions, characterized by anxiety, fear, sweat, associated with pain or painful sensation related to the parenteral administration of drugs (Sarti, 2001).

The clinical manifestations of drug allergy vary and depend on the type and severity, and on the affected organs; the skin is the most frequently affected organ. The prevalence of drug allergy among hospitalized patients is about $0.36 \%$, and the antibiotics are responsible for $55 \%$ of the cutaneous manifestations (Gruchalla, Pirmohamed, 2003).

Drug allergy is induced by immunogenic determinants from the drugs or their metabolites, generally conjugated to proteins (Nagao-Dias et al., 2004). For 
instance, it is known that penicillin presents a major determinant (benzylpenicilloyl group or BPO) and a minor determinants mix (MDM, constituted by benzylpenicilloate, benzylpenicilloyl-amine, and benzylpenicilloic acid, among others). Unfortunately, the immunogenic components from other drugs or their metabolites are in general not identified (Gruchalla, Pirmohamed, 2003), which becomes the laboratory investigation much more difficult.

The only internationally validated test for drug allergy diagnosis is the penicillin cutaneous test. The positivity of the test indicates the presence of $\operatorname{IgE}$ antibodies against the drug and, in this case, the patient has more risk for drug allergy upon re-exposition to the drug (Park, James, 2005). The positive predictive value of the test is considered to be $50 \%$ and the negative predictive value is about 97 to $99 \%$ when the MDM and major determinants (penicilloyl-polyL-lysine or PPL-BPO) are included. The negative results indicate that the patient can be re-exposed to the drug without great risk of immediate reaction after re-exposition (ACAII, 1999; Wall et al., 2004; Park, James, 2005). In case of some reactions occurring after drug re-administration, in patients with positive history of drug allergy and negative cutaneous test, they are generally mild and limited; and anaphylaxis has never been observed in a person with negative cutaneous test results (Gruchalla, Pirmohamed, 2003).

Due to the impossibility to acquire the reagents for the cutaneous test, which are not commercially available in Brazil, a protocol has been proposed by the Brazilian Ministry of Health (Brasil,1999) for obtaining of the penicillin metabolites solution. Nevertheless, little is mentioned in the referred protocol about the implementation of the solution preparation process and the respective test procedure, which becomes difficult the test reproduction in a health service. For this reason, the present work proposes to evaluate the Ministry of Health protocol, according to the good manipulation practices and quality control.

\section{MATERIALS AND METHODS}

The solution preparation was carried out according to the Guide of penicillin cutaneous test from the Ministry of Health (Brasil, 1999).

\section{Reagents preparation}

\section{Potassium G penicillin (PG)- 10,000 U/mL}

From a 1 million units of potassium $G$ penicillin:

A 9.6 mL-solution of isotonic sodium chloride was added to a vial containing 1 million units of potassium $\mathrm{G}$ penicillin, obtaining a 100,000 U/ml-solution. The vial was identified as “ $100,000 \mathrm{U} / \mathbf{m L}$ - potassium $\mathrm{G}$ penicillin stock solution", and kept for no more than 7 days under refrigeration $\left(2\right.$ to $\left.8^{\circ} \mathrm{C}\right)$. Before testing, a solution was prepared aseptically, diluting $1.0 \mathrm{~mL}$ of 100,000 U/mL- potassium $\mathrm{G}$ penicillin solution in $9.0 \mathrm{~mL}$ isotonic sodium chloride. The final solution contained $10,000 \mathrm{U} / \mathrm{mL}$ potassium $\mathrm{G}$ penicillin. This vial was identified as "daily solution of $10,000 \mathrm{U} / \mathrm{mL}$ potassium $\mathrm{G}$ penicillin solution" and left for no more than $24 \mathrm{~h}$ under refrigeration $\left(2\right.$ to $\left.8^{\circ} \mathrm{C}\right)$.

\section{B-Stock solution of sodium benzylpenicilloate}

In a sterile flask with 1 million units, $8.5 \mathrm{~mL}$ of $0.1 \mathrm{~N}$ sodium hydroxide and $1.5 \mathrm{~mL}$ isotonic sodium chloride were added aseptically. After mixing was complete, it was left for $45 \mathrm{~min}$ at room temperature, and then for $48 \mathrm{~h}$ at $4{ }^{\circ} \mathrm{C}$. The flask was identified as "stock solution of $0.125 \mathrm{M}$ sodium benzylpenicilloate" with validity of 30 days and kept under refrigeration $\left(2\right.$ to $\left.8^{\circ} \mathrm{C}\right)$.

Minor determinants mixture preparation (MDM) for daily use (benzylpenicillin/sodium benzylpenicilloate solution)

In a flask containing $8.2 \mathrm{~mL}$ of a sterile sodium chloride solution, we added $1.0 \mathrm{~mL}$ of the stock solution of $100,000 \mathrm{U} / \mathrm{mL}$ diluted penicillin and $0.8 \mathrm{~mL}$ of the stock solution of $0.125 \mathrm{M}$ sodium benzylpenicilloate. After mixing, the flask was labeled as "MDM solution for daily use - 10,000 U/mL potassium $G$ penicillin/ $1.0 \times 10^{-2} \mathrm{M}$ sodium benzylpenicilloate", with validity of $24 \mathrm{~h}$ under refrigeration $\left(2\right.$ to $\left.8^{\circ} \mathrm{C}\right)$.

\section{Cutaneous tests}

\section{Puncture test (prick test)}

Asepsis of the palmar forearm skin surface was done with cotton embedded in 70\% alcohol. After this, "MDM solution for daily use $\mathbf{- 1 0 , 0 0 0 ~} \mathrm{U} / \mathbf{m L}$ potassium $G$ penicillin/ $1.0 \times 10^{-2} \mathrm{M}$ sodium benzylpenicilloate" was aspirated into a $1 \mathrm{~mL}$-syringe and physiological saline (a control solution) into another syringe. One drop of the reagent and one drop of physiological saline were applied in distinct places with a minimal distance of $2 \mathrm{~cm}$ between them on the palmar forearm skin surface. The puncture was done with a disposable pricker, positioned at a $90^{\circ}$ angle in relation to the skin, through a rotation movement. The results interpretation was done after 15 to $20 \mathrm{~min}$. The solutions excess was taken out with an absorbent paper exclusive for each solution. The test was considered negative when no alteration was observed in the application site, in relation to skin color, pruritus or any other sign. The test was considered positive when a more intense response (papules, erythema 
and/or pruritus) occurred, as compared to the physiological solution testing. In case of positive result, the patient would be considered allergic. In case of a negative result, the intradermal testing should be performed.

\section{Intradermal testing}

In two separate syringes with $13 \times 4$ disposable needles, the daily solution of MDM $(10,000 \mathrm{U} / \mathrm{mL}$ of potassium $\mathrm{G}$ penicillin $/ 1 \times 10^{-2} \mathrm{M}$ sodium benzylpenicilloate) and the physiological saline were aspirated. Following, 0.01 to $0.02 \mathrm{~mL}$ of physiological saline (control solution) and the MDM solution were injected in distinct sites, with minimal distances of $2 \mathrm{~cm}$ between the drops on the palmar forearm, observing the formation of a papule with characteristic look of "orange peel". After 15 to $20 \mathrm{~min}$, the readings were done in the same way as the prick test.

A total of 20 individuals were tested, after signing a consent term. One of the participants was a patient attended at the hospital, with background history of penicillin allergy. He did not want to have the drug administered, although penicillin was the drug of choice for his pathology. The other ones were professionals working at the Walter Cantídio University Hospital (WCUH) and students and professionals working at the Faculty of Pharmacy, FUC. A questionnaire was applied to the participants, containing information about previous use and/or occurrence of allergic reactions after administration of penicillin or other beta-lactam drugs, preexisting diseases, current disease, use of medicines and other factors related to a background history of penicillin sensitivity.

The Project was approved by the Ethical Committee of the HUWC/UFC on February $24^{\text {th }} 2004$.

\section{RESULTS AND DISCUSSION}

The tests mostly used for evaluation of immediate hypersensitivity are the cutaneous tests, being extremely useful for evaluation of penicillin allergy. Except for the cutaneous tests, no other test is routinely used in clinics (Cerny et al., 2000; Primeau, Adkinson, 2001).

The test was done in 16 men and 4 women, in the age range between 18 and 54 years old, being the result negative for 19 of twenty participants. A patient attending at the hospital with a previous history of penicillin allergy showed negative results. An employee, for whom the test was positive, had a background history of allergy to potassium diclofenac and trimethoprim-sulphamethoxazole.

\section{Biosafety aspects}

One of the first aspects to take into account is related to the biosafety, of which there is no mention in the Guide of Penicillin Allergy test from the Brazilian Ministry of Health (1999). It is generally mentioned "aseptically" which could just mean a good disinfection of the bench. However, according to the Brazilian normative "Good practice of manipulation for human use in pharmacies" (RDC \# 214, December 12 $2^{\text {th }}, 2006$; ANVISA, Brasil), one must minimize possible risks of contamination during the solution preparation. For this reason, the RDC \# 214, ANVISA (Brasil, 2006), recommends that the area destined to manipulation and bottling of sterile preparations be independent and exclusive, provided with air filters for particle and microorganisms retention, keeping the recommended levels - Class ISO 5 (100 particles/ cubic feet of air) or under laminar flow Class ISO 5 (100 particles/ cubic feet of air), in area Class ISO 7 (10,000 particles/ cubic feet of air) from ISO 14644-1, and presenting positive pressure in relation to the adjacent rooms, avoiding entry of contaminated external air. However, the same normative recommends that the manipulation of antibiotics must be done in an isolated place, inside a room provided with an antechamber. This place should present a negative pressure in relation to the adjacent rooms, being projected in order to avoid spreading of the powder into the laboratory and into the environment, in order to avoid cross contamination, and in this way protecting the manipulator and the environment. It is suggested that all the steps be done in a vertical laminar flow class II- A, with a frontal overture, air source, and exhaustion with HEPA filter for retention of particles and microorganisms, installed preferentially in an independent and exclusive room, including the last step of the preparation, that is, the final dilution of the MDM solution, before its application. The room surrounding the laminar flow must be Class ISO 7 (10,000 particles/ cubic feet of air), present a system of filters to avoid contamination of the environment and must have an antechamber with a clothing room. In this way, the safety of the product, the environment and the manipulators will be maintained, complemented with the use of individual protection equipment (IPE) when preparing the solutions and the adequate procedures of hygiene and cleaning, as washing hands with iodopovidone before and after manipulation.

\section{MDM preparation}

For the MDM preparation, the use of sodium hydroxide of high grade of purity (reagents of analytical purity PA) is paramount. Otherwise the use of sodium hydroxide with lower grade of purity would imply the use of barium hydroxide for the precipitation of possible impurities, as indicated in the Brazilian Pharmacopeia (1926), through 
the following method: initially, $100 \mathrm{~mL}$ of $\mathrm{NaOH}$ solution is prepared adding $0.4 \mathrm{~g}$ sodium hydroxide in recently boiled and cooled water and, following, a freshly prepared saturated solution of barium hydroxide $(2.5 \mathrm{~g}$ barium hydroxide in $50 \mathrm{~mL}$ hot distilled water) is added until no precipitation is formed. The mixture is shaken and left to rest till the following day in a closed flask. The solution is then filtered through a $0.22 \mu \mathrm{m}$ filter (Millipore, USA). The solution is maintained in an sterilized plastic flask and kept during one year at maximum, and it must be tested for the presence of residual barium (Regulation number 500 , October $9^{\text {th }} 1997$, ANVISA, Brasil). It is necessary to check for the presence of residual barium because this can cause skin irritation (Brazil, 1997) and can give false positive results in the cutaneous tests

\section{Test procedure}

In respect to the cutaneous test with application of the MDM solution, it is suggested to use a dermographic pen, marking the sites of application with two traces on the palmar face of the forearm, being one for the test $(\mathrm{T})$ and the other for the control (C), keeping a distance of $2 \mathrm{~cm}$ between them as shown in figure 1. Following the solution application, a disposable pricker is positioned at a $90^{\circ}$ angle on the palmar face of the forearm and rotated $180^{\circ} \mathrm{C}$ in clockwise or anticlockwise sense.

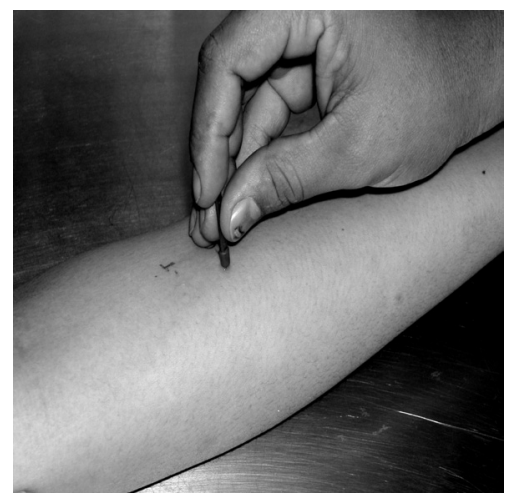

FIGURE 1 - Application of the cutaneous test.

\section{Determinants of penicillin used by cutaneous tests}

The use of the major determinants, that is, BPOPPL, is not referred in the Guide of the Ministry of Health, but a solution containing diluted penicillin G or the MDM, this procedure differs from other papers, in which BPOPPL and MDM are used (Arroliga, Pien, 2003; Gruchalla, 2003; Wall et al., 2004; Lammintausta, KortekangasSavolainen, 2005).
The only major determinants commercially available in the conjugated form of poly-L-lysine (BPO-PPL) was PRE-PEN, nonetheless, its production was interrupted in 2005 (Park, Li, 2005). According to Sarti (1985), although PRE-PEN or BPO-PPL could detect $80 \%$ of the patients who are allergic to penicillin, the risk of immediate hypersensitivity is resultant from reaction to minor determinants.

According to the protocol suggested by the author (Sarti, 2001), which is the same from the Brazilian Ministry of Health (1999), the hydrolysate (MDM) contains benzylpenicilloate and other metabolites in lower quantities. Sarti (1985) considers the solution containing diluted penicillin $\mathrm{G}(\mathrm{PG})$ and minor determinants (MDM) to be effective in identifying patients with risk of larynx edema and anaphylactic shock, making unnecessary the use of BPO-PPL, as the last one just identifies accelerated reactions. Arroliga and Pien (2003) also consider that the greatest risk of severe reactions occurs against the minor determinants; nonetheless, they consider a high risk of anaphylaxis in patients whose tests were positive for any of the determinants, minor or major ones. Concerning the minor determinants, they are not commercially available, for this reason, different ways are proposed for their obtaining. Some authors propose to work with an aged solution of penicillin $\mathrm{G}$, by leaving it at 4 to $8^{\circ} \mathrm{C}$ for a period of 3 to 6 days before its dilution to 10,000 $\mathrm{U} / \mathrm{mL}$ in the tests (Lammintausta, Kortekangas-Savolainen, 2005). However, other researchers are not in agreement with this kind of procedure (Arroliga, Pien, 2003). According to Wall et al. (2004), MDM can be obtained through penicillin dilution to a concentration of $10,000 \mathrm{U} / \mathrm{mL}$ just before the test application. According to Gruchalla and Pirmohamed (2001), with use of freshly diluted penicillin $\mathrm{G}$ in a concentration of $10,000 \mathrm{U} / \mathrm{mL}$ as MDM, one can lose 5 to $10 \%$ of positive tests, making it possible in these cases that a patient presents anaphylaxis upon re-administration of penicillin.

In contraposition to the authors' considerations, Sarti (1985) reports that 6,668 patients with negative results to MDM and diluted PG were treated without presenting any immediate allergic reaction, estimating a risk of systemic reaction of 1.5 per million of individuals with negative test upon re-administration of penicillin. This reinforces the hypothesis that the "in house" prepared method, as suggested by the author (Sarti, 1985), is reliable and safe for the evaluation of penicillin allergy.

\section{Interpretation of the results}

Concerning the interpretation of the results, according to the protocol of the Brazilian Ministry of Health (1999), the result is considered negative when there is no alteration observed on the site of application, in respect 
to the skin color, to pruritus or any other kind of sign not referred by the patient. The result is considered positive, when there is a papule elevation (with or without erythema surrounding it), erythema and/or pruritus at the site of application, with a diameter at least $2 \mathrm{~mm}$ larger than the control. Other authors (Arroliga, Pien, 2003), differing from the protocol of the Brazilian Ministry of Health (1999), considered the results positive when the diameter of the test was at least $3 \mathrm{~mm}$ larger than the control, with erythema. Wall et al. (2004) include histamine as positive control. According to the authors, when both the penicillin and the histamine show reaction, the test is considered positive. In case the histamine shows a reaction, but not the penicillin, the test is considered negative. In this case, the risk of penicillin allergy is considered to be similar to the population in general. On the other hand, when the test is negative both for histamine and penicillin, it is interpreted as undetermined. The concentration of histamine is generally $1 \mathrm{mg} / \mathrm{mL}$ (Cetinkaya, Cag, 2004; Wall et al., 2004; Lammintausta, Kortekangas-Savolainen, 2005).

\section{Consent term}

In respect to the consent term, there is a diversity of opinions. According to Wall et al. (2004), when the patient is directed to an allergy test service, and he agrees with it, the pharmacist proceeds with the test, without the necessity of a formal consent, once the procedure has not an experimental character. According to Torres et al. (2003), in case the patient has a possible allergy reaction to a drug, the tests do not require an approval by a local ethics committee, just a written informed consent. The authors consider an approval by an ethics committee is necessary when the diagnostic methods are used in the context of clinical studies, for establishing the right dose for a cutaneous test, for instance, or a validation for a provocation test, and also, when the data are kept or distributes through a data bank.

\section{CONCLUSIONS}

The implementation of the penicillin cutaneous test was necessary for allowing the reproducibility and quality of the procedure. This way, we could elaborate standard operational procedures for the preparation of penicillin cutaneous test for hospital routine. Considering that the MDM-PG solution is for parenteral use, its preparation must be done in aseptic environment, by trained personal, in order to diminish the risk of contamination and to guarantee the solution sterility.

\section{ACKNOWLEDGEMENT}

The present work is part of a pharmaceutical assistance project supported by MCT/CNPq/MS-SCTIEDECIT-DAF 54/2005, process 402509/2005-6.

\section{REFERENCES}

ACAAI (AMERICAN COLLEGE OF ASTHMA \& IMMUNOLOGY). Annotation of the algorithm for disease management of drug hypersensitivity. Ann. Allergy Asthma Immunol., v.83, pt.3 suppl., p.667-671, 1999.

ARROLIGA, M.E; PIEN, L. Penicillin allergy: Consider trying penicillin again. Cleveland Clin. J. Med., v.70, p.313-326, 2003.

BRASIL. Ministério da Saúde. Secretaria de Políticas de Saúde. Coordenação nacional de DST e Aids - Manual de teste de sensibilidade à penicilina. Brasília, 1999. Available at: $<h t t p: / / w w w . a i d s . g o v . b r / t e s t e s \_$penicilina.pdf $>$. Accessed on: 22 aug. 2005.

BRASIL. Ministério da Saúde. Secretaria de Vigilância Sanitária. Dispõe sobre Boas Práticas de Manipulação de Medicamentos para Uso em Humanos em farmácias. RDC $\mathrm{n}^{\circ}$ 214. Brasília, de 12 de dezembro de 2006. Available at: $<$ http://www.anvisa.gov.br/legis/index.htm>. Accessed on: 22 oct. 2007.

BRASIL. Ministério da Saúde. Secretaria de Vigilância Sanitária. Aprova o Regulamento Técnico de Soluções Parenterais de Grande Volume - SPGV e seus Anexos. Portaria ${ }^{\circ} 500$. Brasília, 09 de outubro de 1997. Available at: <http://www.anvisa.gov.br>. Accessed on: 22 oct. 2007.

BRASIL. Ministério da Saúde. Secretaria de Vigilância Sanitária. Anexo 1 in Cartas aos profissionais de saúde. Nota técnica sobre suspeitas de reações adversas graves com o medicamento CELOBAR SUSPENSÃO ${ }^{\circledR}$. Available at: $<$ http://www.anvisa.gov.br>. Accessed on: 22 oct. 2007.

CERNY,A.; NEFTEL, K.A.; FUX, C.; HOIGNÉ, R. Penicillins. In: DUJES, M.N.G.; ARONSON, J.K., (Eds.). Meyler's side effects of drugs. 14.ed. New York: Elsevier, 2000. p.810-820.

CETINKAYA, F.; CAG, Y. Penicillin sensitivity among children without a positive history for penicillin allergy. Pediatr. Allergy Immunol., v.15, p.278-280, 2004. 
FARMACOPÉIA BRASILEIRA. São Paulo: Companhia Editora Nacional, 1926. 1062 p.

FORREST, D.M.; SCHELLENBERG, R.R.; THIEN, VV.S.; KING, S.; ANIS, A.H.; DODEK, P.M. Introduction of a practice guideline for penicillin skin testing improves the appropriateness of antibiotic therapy. Clin. Infectious Dis., v.32, p.1685-1690, 2001.

GRUCHALLA R.; PIRMOHAMED, M. Antibiotic allergy. $N$. Engl. J. Med., v.354, p.601-609,2006.

GRUCHALLA, R.S. Drug allergy. J. Allergy Clin. Immunol., v.111, p.S548-559, 2003.

LAMMINTAUSTA K.; KORTEKANGAS-SAVOLAINEN, O. The usefulness of skin tests to prove drug hypersensitivity. Br. J. Dermatol., v.152, p.968-974, 2005.

NAGAO-DIAS, A.T.; BARROS-NUNES, P.; COELHO, H.L.L.; SOLÉ, D. Reações alérgicas a medicamentos. $J$. Pediatr., v.80, p.259-266, 2004.

PARK, M.A.; LI, J.T.C. Diagnosis and management of penicillin allergy. Mayo Clin. Proc., v.80, p.405-410, 2005.

PRIMEAU, M.N.; ADKINSON Jr., NF. Recent advances in the diagnosis of drug allergy. Curr. Opin Allergy Clin. Immunol, v.1, p.337-341, 2001.
SÃO PAULO (Estado). Secretaria Municipal de Saúde. Instrução técnica para a prescrição e a utilização de penicilinas. Prefeitura de São Paulo. 2003. Available at: <http://www.fesehf.org.br/circulares.html.2003/ circulares $>$. Accessed on: 4 apr. 2004.

SARTI, W. Alergia a drogas: penicilinas, cefalosporinas, sulfonamidas e insulina. In: GRUMACH, A.S. Alergia e imunologia na infância e na adolescência. São Paulo: Atheneu, 2001. chap.23, p.265-280.

SARTI,W. Routine use of skin testing for immediate penicillin allergy to 6,764 patients in an outpatient clinic. Ann. Allergy, v.55, p.157-161,1985.

TORRES, M.J.; BLANCA, M.; FERNANDEZ, J.; ROMANO, A.; WECK, A.; ABERER, W.; BROCKOW, K.; PICHLER, W.J.; DEMOLY, P. Diagnosis of immediate allergic reactions to beta-lactam antibiotics. Allergy, v.58, p.961$972,2003$.

WALL, G.C.; PETERS, L.; LEADERS, C.B.; WILLE, J.A. Pharmacist-managed service providing penicillin allergy skin tests. Am. J. Health-Syst. Pharm., v.61, p.1271-2175, 2004.

Received for publication on $14^{\text {th }}$ December 2007 Accepted for publication on $13^{\text {th }}$ March 2009 